\title{
The safety of infliximab infusions in the community setting
}

\author{
James Ducharme MD ${ }^{1}$, Cindy Pelletier $\mathrm{MSc}^{2}$, Ramesh Zacharias $\mathrm{MD}^{3}$
}

\begin{abstract}
J Ducharme, C Pelletier, R Zacharias. The safety of infliximab infusions in the community setting. Can J Gastroenterol 2010;24(5):307-311.
\end{abstract}

BACKGROUND: Tumour necrosis factor-alpha (TNF $\alpha$ ) has an important role in the pathogenesis of inflammatory conditions such as rheumatoid arthritis, Crohn's disease, ulcerative colitis and psoriasis. Infliximab, a chimeric anti-TNF $\alpha$ monoclonal antibody, has been shown to reduce the severity of symptoms or induces remission of active disease. Infusions have generally been limited to the hospital setting due to cost and concerns for patient safety. Studies defining its efficacy and safety have, therefore, originated almost exclusively from hospital settings.

OBJECTIVE: To evaluate the safety of infliximab in a community clinic environment, across all types of patients.

METHODS: A retrospective chart review of 3161 patients who received a combined 20,976 infusions at a network of community clinics over 16.5 months was conducted. Adverse drug reaction (ADR) information was retrieved and coded for time of onset, severity and outcome. Only ADRs that occurred during or within the first $24 \mathrm{~h}$ of the infusion were included.

RESULTS: A total of 524 (2.5\% of all infusions) acute ADRs in 353 patients $(11.2 \%)$ were recorded. Most reactions (ie, ADRs) were mild $(n=263[50.2 \%, 1.3 \%$ of all infusions $])$ or moderate $(n=233[44.5 \%$, $1.1 \%$ of all infusions]). Twenty-eight reactions $(5.3 \%, 0.1 \%$ of all infusions) were severe. Emergency medical services were called to transport patients to hospital for seven of the severe reactions, of which none required admission. As per pre-established medical directives, adrenaline was administered three times.

CONCLUSIONS: Infliximab infusions are safe in the community setting. Severe ADRs were rare. None required active physician intervention; nurses were able to treat all reactions by following standardized medical directives.

\section{L'innocuité des infusions d'infliximab en milieu communautaire}

HISTORIQUE : Le facteur de nécrose tumorale alpha (TNF $\alpha$ ) a un rôle important dans la pathogenèse des états inflammatoires comme la polyarthrite rhumatoïde, la maladie de Crohn, la colite ulcéreuse et le psoriasis. Il est démontré que l'infliximab, un anticorps monoclonal antiTNF $\alpha$ chimérique, réduit la gravité des symptômes ou induit une rémission de la maladie active. En général, les infusions sont limitées au milieu hospitalier en raison des coûts et des préoccupations quant à la sécurité des patients. Ainsi, les études en définissant l'efficacité et l'innocuité proviennent presque exclusivement des milieux hospitaliers.

OBJECTIF : Évaluer l'innocuité de l'infliximab dans un environnement clinique communautaire, chez tous les types de patients.

MÉTHODOLOGIE : Les chercheurs ont effectué une analyse rétrospective des dossiers de 3161 patients qui avaient reçu une combinaison de 20976 infusions dans un réseau de cliniques communautaires pendant une période de 16,5 mois. Ils ont saisi l'information liée aux effets médicaux indésirables (EIM) et l'ont codée pour en dégager le moment d'apparition, la gravité et l'issue. Seuls les EIM qui s'étaient produits dans les 24 heures suivant l'infusion étaient inclus.

RÉSULTATS : Au total, les chercheurs ont dénombré 524 EIM aigus (2,5\% de toutes les infusions) chez 353 patients $(11,2 \%)$. La plupart des réactions (les EIM) étaient bénignes ( $\mathrm{n}=263$ [50,2\%, 1,3\% de toutes les infusions]) ou modérées ( $\mathrm{n}=233$ [44,5\%, 1,1\% de toutes les infusions]). Vingt-huit réactions $(5,3 \%, 0,1 \%$ de toutes les infusions) étaient graves. On a dû appeler les services médicaux d'urgence pour transporter les patients à l'hôpital dans sept des réactions graves, mais aucune n'a exigé d'hospitalisation. Conformément aux directives médicales préétablies, on a administré de l'adrénaline trois fois.

CONCLUSIONS : Les infusions d'infliximab sont sécuritaires en milieu communautaire. Les EIM graves sont rares. Aucune n'a exigé l'intervention active d'un médecin. Les infirmières ont été en mesure de traiter toutes les réactions en respectant des directives médicales normalisées.

Key Words: Adverse events; Community setting; Infliximab; Safety

7 umour necrosis factor alpha $(\mathrm{TNF} \alpha)$ is a proinflammatory cytokine that has an important role in the pathogenesis of many inflammatory conditions including rheumatoid arthritis, Crohn's disease, ulcerative colitis and psoriasis (1-6). Infliximab, a chimeric monoclonal antibody binds with high-affinity to TNFa, thereby neutralizing its biological activity (7-9). Infliximab has demonstrated a potent clinical effect in the above diseases by either reducing the severity of symptoms thereby improving the quality of life - or inducing remission of active disease.

When given in a controlled environment, such as in a clinical study or hospital environment, infliximab has demonstrated a relatively good safety profile. There have been several publications defining and evaluating long-term risks that include infection, reactivation of granulomatous disease, lupustype reactions, new malignancies and congestive heart failure (10-14). With regard to short-terms risks, however, reporting and classifications have been inconsistent.

Cheifetz and Mayer (7) recommended a stratification of acute adverse drug reaction (ADR) (Table 1). They classified acute ADRs into either mild, moderate or severe, and outlined the suggested course of action for each. Despite this, most studies have tended to place all acute adverse events into one general category. For example, A Crohn's Disease Clinical Trial Evaluating Infliximab in a New Long-Term Treatment (ACCENT) I study grouped all acute ADRs together, irrespective of severity (15). Serum sickness reactions were also placed under the category of acute infusion reactions. A severe

${ }^{1}$ Department of Medicine, McMaster University, Hamilton; ${ }^{2}$ AIM Health Group; ${ }^{3}$ Centres for Pain Management, Mississauga, Ontario

Correspondence: Dr James Ducharme, 9-6400 Millcreek Drive, Mississauga, Ontario L5N 3E7. Telephone 905-858-1368,

fax905-858-1399, e-mail jducharme@aimhealthgroup.com

Received for publication September 2, 2009. Accepted October 15, 2009 
TABLE 1

Infusion protocol outlined by Cheifetz and Mayer (7)

\begin{tabular}{|c|c|c|}
\hline Reaction type, symptoms & Treatment protocol & Prophylaxis \\
\hline Mild & Slow infusion rate to $10 \mathrm{~mL} / \mathrm{h}$ & \multirow{4}{*}{$\begin{array}{l}\text { Pretreat with diphenhydramine } 25 \mathrm{mg} \text { to } 50 \mathrm{mg} \text { and } \\
\text { acetaminophen } 650 \mathrm{mg} \text { PO } 1.5 \mathrm{~h} \text { before infusion } \\
\text { (Five days of a second-generation antihistamine can be } \\
\text { substituted to decrease sedation) }\end{array}$} \\
\hline Flushing & Infuse normal saline $(500 \mathrm{~mL} / \mathrm{h}$ to $1000 \mathrm{~mL} / \mathrm{h})$ & \\
\hline Dizziness & Diphenhydramine $25 \mathrm{mg}$ to $50 \mathrm{mg}$ IVPB & \\
\hline Headache & Acetaminophen $650 \mathrm{mg}$ & \\
\hline Diaphoresis & Monitor vital signs every $10 \mathrm{~min}$, until within normal limits & \multirow{3}{*}{$\begin{array}{l}\text { Test dose at } 10 \mathrm{~mL} / \mathrm{h} \text { before for } 15 \mathrm{~min} \text {. Increase infusion } \\
\text { rate to } 20 \mathrm{~mL} / \mathrm{h}, 40 \mathrm{~mL} / \mathrm{h}, 80 \mathrm{~mL} / \mathrm{h}, 100 \mathrm{~mL} / \mathrm{h} \text {, } \\
125 \mathrm{~mL} / \mathrm{h} \text { every } 15 \mathrm{~min} \text {, as tolerated }\end{array}$} \\
\hline Nausea & Wait $20 \mathrm{~min}$, then increase infusion rate to $20 \mathrm{~mL} / \mathrm{h}$ & \\
\hline Palpitations & $\begin{array}{l}\text { for } 15 \mathrm{~min} \text {, then } 40 \mathrm{~mL} / \mathrm{h}, 80 \mathrm{~mL} / \mathrm{h}, 100 \mathrm{~mL} / \mathrm{h} \text {, } \\
125 \mathrm{~mL} / \mathrm{h} \text { every } 15 \mathrm{~min} \text {, as tolerated }\end{array}$ & \\
\hline
\end{tabular}

\section{Moderate}

Chest discomfort

Shortness of breath

Hypo/hypertension ( $>20$ points SBP)

Increased temperature

Palpitations

Urticaria

\section{Severe}

Hypo/hypertension (>40 points SBP)

Increased temperature with rigors

Chest discomfort

Shortness of breath with wheezing

Stridor (if potential to lose airway, call

emergency medical services for

transport to emergency room)

Flushing
Slow infusion rate to $10 \mathrm{~mL} / \mathrm{h}$ or stop infusion

Acetaminophen $650 \mathrm{mg}$

Monitor vital signs every 5 min until within normal limits

Wait $20 \mathrm{~min}$, then restart infusion at $10 \mathrm{~mL} / \mathrm{h}$ for $15 \mathrm{~min}$

Increase infusion rate to $20 \mathrm{~mL} / \mathrm{h} \times 15 \mathrm{~min}$, then

$40 \mathrm{~mL} / \mathrm{h}, 80 \mathrm{~mL} / \mathrm{h}, 100 \mathrm{~mL} / \mathrm{h}, 125 \mathrm{~mL} / \mathrm{h}$ every

$15 \mathrm{~min}$, as tolerated

\section{Stop infusion}

Infuse normal saline $(500 \mathrm{~mL} / \mathrm{h}$ to $1000 \mathrm{~mL} / \mathrm{h})$

Maintain airway; oxygen if available

Adrenaline (1:1000) $0.1 \mathrm{~mL}$ to $0.5 \mathrm{~mL}$ subcutaneous

(may repeat every $5 \mathrm{~min} \times 3$ )

Diphenhydramine $25 \mathrm{mg}$ to $50 \mathrm{mg}$ IVPB

Hydrocortisone $100 \mathrm{mg}$ IV or methylprednisolone

$20 \mathrm{mg}$ to $40 \mathrm{mg} \mathrm{IV}$

Monitor vital signs every 2 min until within normal limits

If patient stabilizes, wait $20 \mathrm{~min}$, then restart infusion

at $10 \mathrm{~mL} / \mathrm{h}$ for $15 \mathrm{~min}$

Increase infusion rate to $20 \mathrm{~mL} / \mathrm{h} \times 15 \mathrm{~min}$, then

$40 \mathrm{~mL} / \mathrm{h}, 80 \mathrm{~mL} / \mathrm{h}, 100 \mathrm{~mL} / \mathrm{h}, 125 \mathrm{~mL} / \mathrm{h}$ every

$15 \mathrm{~min}$, as tolerated

If patient requires second dose of adrenaline, call

emergency medical services and transfer patient to emergency room for monitoring

\section{Delayed}

Rash/urticaria

Myalgias

Flu-like symptoms

Joint stiffness and pain

Headache
Acetaminophen $650 \mathrm{mg}$ to $1000 \mathrm{mg}$ PO QID

Second-generation antihistamine or diphenhydramine

$50 \mathrm{mg}$ QD to BID

Methylprednisolone dose pack if joint pain is severe
Pretreat with diphenhydramine $25 \mathrm{mg}$ to $50 \mathrm{mg}$ and acetaminophen $650 \mathrm{mg}$ PO $1.5 \mathrm{~h}$ before infusion (Five days of a second-generation antihistamine can be substituted to decrease sedation)

Test dose at $10 \mathrm{~mL} / \mathrm{h}$ before for $15 \mathrm{~min}$. Increase infusion rate to $20 \mathrm{~mL} / \mathrm{h}, 40 \mathrm{~mL} / \mathrm{h}, 80 \mathrm{~mL} / \mathrm{h}, 100 \mathrm{~mL} / \mathrm{h}, 125 \mathrm{~mL} / \mathrm{h}$ every $15 \mathrm{~min}$, as tolerated

Prednisone 50 mg PO every 12 h BID $\times 3$ doses before infusion or

Hydrocortisone $100 \mathrm{mg}$ IV or methylprednisolone $20 \mathrm{mg}$ to $40 \mathrm{mg}$ IV before infusion

Pretreat with diphenhydramine $25 \mathrm{mg}$ to $50 \mathrm{mg}$ and acetaminophen $650 \mathrm{mg}$ PO $1.5 \mathrm{~h}$ before infusion (Five days of a second-generation antihistamine can be substituted to decrease sedation)

Test dose at $10 \mathrm{~mL} / \mathrm{h}$ before $\times 15 \mathrm{~min}$. Increase infusion rate to $20 \mathrm{~mL} / \mathrm{h}, 40 \mathrm{~mL} / \mathrm{h}, 80 \mathrm{~mL} / \mathrm{h}, 100 \mathrm{~mL} / \mathrm{h}$ every $15 \mathrm{~min}$, as tolerated

\begin{abstract}
Pretreat with diphenhydramine $25 \mathrm{mg}$ to $50 \mathrm{mg}$ and acetaminophen $650 \mathrm{mg}$ PO $1.5 \mathrm{~h}$ before infusion (Five days of a second-generation antihistamine can be substituted to decrease sedation)

Test dose at $10 \mathrm{~mL} / \mathrm{h}$ before for $15 \mathrm{~min}$

Increase rate to infuse over $3 \mathrm{~h}$

Acetaminophen $650 \mathrm{mg}$ to $1000 \mathrm{mg}$ PO QID for

3 days postinfusion

Second-generation antihistamine for 7 days postinfusion

Send home with methylprednisolone dose pack if joint pain is severe
\end{abstract}

BID Twice daily; IV Intravenous; IVPB IV piggyback; PO Orally; QD Once a day, QID Four times a day; SBP Systolic blood pressure

reaction seemed to be defined by the study patient being unable to continue the active medication, although there appeared to have been no a priori explicit criteria for withdrawal based on acute ADR. In a study by Colombel et al (16), a serious adverse event was defined as an event that led "to or prolonged hospitalization, was fatal or life threatening or that resulted in significant disability". Unfortunately, such implicit criteria are subjective and difficult to reproduce. Furthermore, what may not appear serious in a closely monitored clinical trial or within the confines of a hospital, may be considered serious in a clinic or outpatient setting.

To date, publications describing acute ADRs have been limited to the hospital environment or within the confines of clinical trials. Patients in these publications were preselected and did not represent the full spectrum of patients who might receive infliximab. Such an approach maximizes potential benefit (efficacy) while minimizing risk. Postmarketing studies that include 'all comers' usually demonstrate less benefit (effectiveness), while often identifying greater harm. Therefore, it is important for such community studies to be performed. The goal of the present study was to evaluate the safety of infliximab in a community clinic environment, across all types of patients.

\section{METHODS}

The current retrospective chart review reports on the infusion reaction rate seen in all patients treated with infliximab in community infusion clinics during the period from December 1, 2006 to April 15, 2008. The multiple infusion clinics located across Ontario followed standardized protocols for the infusion and monitoring of infliximab. Such an approach has been in place for more than six years, with an accumulated total of more than 100,000 infusions. 
TABLE 2

Patients according to primary diagnosis

\begin{tabular}{lc}
\hline Primary diagnosis & $\mathbf{n}(\%)$ \\
\hline Crohn's disease & $1401(44.3)$ \\
Rheumatoid arthritis & $663(21.0)$ \\
Ulcerative colitis & $352(11.1)$ \\
Fistulizing Crohn's disease & $283(9.0)$ \\
Ankylosing spondylitis & $219(6.9)$ \\
Psoriatic arthritis & $91(2.9)$ \\
Psoriasis & $43(1.4)$ \\
Other & $109(3.4)$ \\
Total & $3161(100.0)$ \\
\hline
\end{tabular}

All patients had been referred to one of the pre-established infusion clinics by their primary care physician or specialist for infusions of infliximab at a dose established by that physician. Referred patients were diagnosed with one of the following: inflammatory bowel disease - including ulcerative colitis and Crohn's disease, rheumatoid arthritis, psoriasis or uveitis. The decision to use premedications (eg, antihistamines, steroids and/or acetaminophen) was also made by the referring physician. Patients would initially receive three loading doses at zero, two and six weeks, followed by maintenance infusions at intervals determined by their referring physician (typically every six or eight weeks). On arrival to the clinic, patients were first assessed for abnormalities in vital signs, active infections, recent vaccinations and recent surgery. If all was normal, they received any prescribed premedication and then received infliximab over a $2 \mathrm{~h}$ period. In case of abnormality, the onsite physician was contacted for further instructions. During the infusion, vital signs were monitored and recorded every $30 \mathrm{~min}$; a nurse was expected to be with no more than three patients for any one infusion period. Postinfusion, patients were observed for $1 \mathrm{~h}$ for side effects and, on discharge, were advised to seek medical attention should any side effect occur. All nurses received standardized training regarding the mixing and infusion of infliximab, as well as the recognition and management of any related acute ADRs. A physician was on site for the duration of each infusion session but was not restricted to that sole task, routinely seeing his regular patients in another area. All physicians received a $1 \mathrm{~h}$ education session about infliximab, including the recognition and management of potential acute adverse drug events related to its infusion.

Any ADRs occurring during the $3 \mathrm{~h}$ stay were addressed as per the protocol detailed in Table 1 and noted by the nurse on a standardized adverse event form. Patients were asked to advise the nurse of any novel symptoms they were feeling. Patients were asked to call the $24 \mathrm{~h}$ hotline to advise the clinic coordinator and/or referring physician of any symptoms that arose after departure from the clinic. If such a call was received, an adverse event form was completed. In an effort to capture all ADRs, the patients were asked at their next appointment about any possible acute ADR they had failed to report. After every documented adverse event, both the referring physician and Schering-Plough Canada were notified by fax.

The data required for the present retrospective chart review were partly available in an existing electronic database, while the rest were available in the paper hardcopy of the patient records. Every new patient had an electronic record containing general patient profile and appointment data that was mostly
TABLE 3

Patients according to premedications

\begin{tabular}{lc}
\hline Premedication(s) & $\mathbf{n}(\%)$ \\
\hline None & $1100(34.8)$ \\
Antihistamines & $230(7.3)$ \\
Acetaminophen & $102(3.2)$ \\
Steroids & $597(18.9)$ \\
Antihistamines and acetaminophen & $227(7.2)$ \\
Antihistamines and steroids & $323(10.2)$ \\
Acetaminophen and steroids & $82(2.6)$ \\
Antihistamines, acetaminophen and steroids & $500(15.8)$ \\
Total & $3161(100.0)$ \\
\hline
\end{tabular}

used to schedule appointments. The hardcopy of a patient's record is a standardized datasheet that was completed at each visit, and included weight, presence and level of severity of new symptoms, history of infection(s) or hospitalization(s) since the previous infusion, recent surgery or planned surgery, blood tests, or other investigations (eg, colonoscopy) and any change in medications. Details on any previous or new ADRs were included in the hardcopy of the patient's record.

The required electronic data elements were extracted from the database and supplemented with data extracted from paper records. The data elements obtained from the electronic database were the following: age, diagnosis, weight, infusion intervals, infliximab dosage, number of infusions received during the study period and medications to be taken before infliximab infusion. The data extracted from the paper records were the following: steroid premedication dosage, azathioprine use, severity of adverse event according to Cheifetz and Mayer's (7) stratification and onset of adverse event (during infusion, within $24 \mathrm{~h}$ postinfusion or delayed).

\section{RESULTS}

In total, 3161 patients received a combined 20,976 infusions during the study period. All infusions performed during the study period were included in the analyses. While most patients were already receiving infliximab at the start of data collection, 778 new patients were started during the study period. Patients ranged in age from 10 to 92 years, with a mean and median age of 44 years. Females represented $54.1 \%(n=1711)$ of the population. Patients received a mean of 6.64 (median seven) infusions during the study period. The mean weight of patients was $75.26 \mathrm{~kg}$ (median $73 \mathrm{~kg}$ ). The mean infliximab dose was $5.16 \mathrm{mg} / \mathrm{kg}$ of body weight (median $5 \mathrm{mg} / \mathrm{kg}$ ). The average time between infusions was 7.37 weeks (median eight weeks, range four to 20 weeks), with the great majority of infusions $(91.5 \%, n=16,478)$ occurring within six to eight weeks. The most common diagnoses were Crohn's disease and rheumatoid arthritis. The range of primary diagnoses are summarized in Table 2. The majority of patients $(75.2 \%, \mathrm{n}=2061)$ were prescribed premedications. The most frequently used premedications were steroids $(47.5 \%, \mathrm{n}=1502$ [hydrocortisone in $97.4 \%$ of cases]). Further details on the types and combinations of premedications prescribed are outlined in Table 3.

Adverse events were categorized according to their onset and severity. In total, 884 (4.2\% of all infusions) adverse events in 597 patients (18.9\%) were recorded. Of these, 353 (39.9\%) were delayed (ie, more than $24 \mathrm{~h}$ after infusion). The reactions after discharge were heterogeneous and included possible 


\begin{tabular}{lrr}
$\begin{array}{l}\text { TABLE } \mathbf{4} \\
\text { Moderate and severe adverse drug reactions and } \\
\text { proportion of infusions for each primary diagnosis }\end{array}$ \\
\hline & \multicolumn{2}{c}{ Adverse drug reaction, $\mathbf{n}(\%)$} \\
\cline { 2 - 3 } Primary diagnosis & \multicolumn{1}{c}{ Moderate } & Severe \\
\hline Psoriatic arthritis & $7(1.1)$ & $2(0.3)$ \\
Rheumatoid arthritis & $47(1.0)$ & $11(0.2)$ \\
Ulcerative colitis & $42(2.2)$ & $4(0.2)$ \\
Fistulizing Crohn's disease & $18(1.1)$ & $2(0.1)$ \\
Crohn's disease & $84(0.9)$ & $8(0.1)$ \\
Ankylosing spondylitis & $24(1.6)$ & $1(0.1)$ \\
Psoriasis & $1(0.5)$ & $0(0.0)$ \\
Other & $10(1.3)$ & $0(0.0)$ \\
Total & $233(1.1)$ & $28(0.1)$ \\
\hline
\end{tabular}

symptoms from infliximab infusion as well events most likely unrelated to the medication such as hospitalization for elective surgery. Given the voluntary nature of these reports and the inclusion of arguably unrelated events, subsequent analysis and discussion will focus on acute adverse events occurring within $24 \mathrm{~h}$ of the infusion.

There were 524 acute ADRs, of which 405 (1.9\% of all infusions) occurred during the infusion and 119 ADRs (0.6\% of all infusions) occurred within $24 \mathrm{~h}$, for an overall acute ADR rate of $2.5 \%$. The ADRs occurred in 353 patients $(11.2 \%)$, of which 37 (10.5\% or $1.2 \%$ of all patients) were receiving infliximab for the first time. Patients with certain primary diagnoses $\left(\chi^{2}=40.812\right.$, degrees of freedom $\left.[\mathrm{df}]=7 ; \mathrm{n}=20,976, \mathrm{P}<0.01\right)$ and younger patients $\left(\chi^{2}=23.438, \mathrm{df}=6 ; \mathrm{n}=20,966, \mathrm{P}<0.01\right)$ were more likely than others to experience an ADR (see Table 4 for further details on the occurrence of moderate and severe ADR by primary diagnosis, and Table 5 for the ADR rate and count for each age group). Women $\left(\chi^{2}=23.722, \mathrm{df}=1 ; \mathrm{n}=20,976\right.$, $\mathrm{P}<0.01)$ were more likely to experience an ADR $(2.9 \%$ ADR rate per infusion versus $1.9 \%$ for men). Finally, patients receiving their first infusion had an acute ADR rate of $4.8 \%$ ( $n=37$ of 778 patients) - a rate statistically higher than the overall rate of $2.5 \%\left(\chi^{2}=16.794, \mathrm{df}=1 ; \mathrm{n}=20,931, \mathrm{P}<0.01\right)$.

Overall, most reactions were mild $(n=263,50.2 \%$ of 524 ADRs [1.3\% of all infusions]) or moderate ( $n=233,44.5 \%, 1.1 \%$ of all infusions), with 28 being severe $(5.3 \%, 0.1 \%)$. As required by protocol, emergency medical services were called to transport patients to hospital for seven of the severe reactions. Adrenaline was administered only three times. No patient required hospital admission.

Complete resolution of ADRs occurred in $75.6 \%$ of patients before discharge from the clinic, with improvement noted in an additional $15.1 \%$. Twelve acute ADRs (2.3\% [0.06\% of all infusions]) remained unchanged up to the time of the report. These persistent ADRs were either mild or moderate, and included symptoms such as pruritis, headache, elevated blood pressure, tingling, flushing, joint pain, chills, dry skin and elevated body temperature. All severe acute ADRs were reported as resolved $(n=11)$ or improved $(n=14)$. For the severe reactions requiring emergency medical services, all were reported as improved or resolved before the patient left the clinic.

Furthermore, all infusions were completed except for 47 (9\% of 524 [0.2\% of all infusions]) administered to 39 patients due to ADRs. Nineteen $(0.09 \%)$ ADRs were reported as resolved while $28(0.13 \%)$ were reported as improved by the time the
TABLE 5

Adverse drug reactions and proportion for each age group

\begin{tabular}{lr}
\hline Age group, years & $\mathbf{n}(\%)$ \\
\hline 18 and younger & $16(4.8)$ \\
$19-34$ & $144(2.9)$ \\
$35-44$ & $136(2.9)$ \\
$45-54$ & $114(2.3)$ \\
$55-64$ & $60(1.8)$ \\
$65-74$ & $38(2.1)$ \\
75 and older & $16(1.7)$ \\
Total & $524(2.5)$ \\
\hline
\end{tabular}

patient left the clinic. Of those 39 patients, 10 patients maintained their scheduled infliximab treatment plan and returned for their following scheduled infusion, while 27 patients did not return for further infusions. The return status of two patients was unknown because their ADR occurred near the end of the study and their next scheduled infusion was beyond the study period.

\section{DISCUSSION}

In almost all clinical studies, infliximab has been infused in a controlled setting, either in hospital clinics or to admitted patients on a ward. Studies are more easily controlled in such an environment. In addition, concerns for patient safety due to ADRs during infliximab infusion - have continued to restrict these infusions to hospital settings. Such a restriction is often inconvenient for many patients due to travel requirements. It may also provide inefficient care, asking patients to stay for many hours longer than the infusion itself requires. Such concern over patient safety may not be justified. While $3 \%$ of patients in ACCENT I had their treatment suspended due to adverse events (15), only two of 2211 infusions in a study by Colombel et al (16) 'required' the use of adrenaline. In a study by Takeuchi et al (17), the rate of serious adverse events was also low, occurring in $0.5 \%$. Most reactions considered serious can be controlled by temporary cessation of the infusion, followed by a slower infusion rate when restarted. They do not necessarily require treatment, as is often suggested.

Cheifetz and Mayer (7) have demonstrated that ADRs are not related to the presence of antibodies. They stated that "the reactions are largely not anaphylactic (IgE mediated), making it possible to re-treat patients using specific protocols". Such information further supports the concept that use of adrenaline - as is recommended for anaphylaxis - may be of no value for infliximab-related acute adverse events.

Our study evaluated the safety of infliximab infusions administered in a community setting using a standardized protocol, and is the largest report of acute adverse event rates to date. The results demonstrate convincingly that infliximab can be infused in a community clinic without untoward patient risk. Furthermore, it would appear that the onsite presence of a physician - as required in Canada - may not be warranted, provided appropriate medical directives are in place.

While our study's per-infusion reaction rate was low, the per-patient rate was higher than that previously reported. It has been suggested that the greater the number of infusions a patient receives, the more likely it is that that patient will experience at least one ADR. As stated above, Cheifetz and 
Mayer (7) have demonstrated that the reactions are not related to antibody formation. If infusion reactions were related to antibody formation, one would expect that there could be no such reactions with a first infusion. Our study found the exact opposite: the acute ADR rate was almost twice as high in firsttime infusions than was seen overall.

Any therapy that has the potential to place a patient at risk of a serious adverse event should be performed in a monitored setting. Identifying the true risk to patients from acute infusion reactions requires a large cohort. To date, most studies have focused on delayed or longer-term risk, which fails to establish the safety of the infusion itself. The severity of acute infusion reactions has been difficult to characterize because adverse events are often grouped together in randomized trials studying therapeutic effects, and are only reported in a single paragraph. Justifiably, there has been a focus on risk of infection after the infusion and on risk of malignancy at some point thereafter. While of high importance, such studies do not enable the patient or the physician to know if monitoring is required or whether treatment should take place in a hospital setting. Our results establish that the practice of infusing infliximab in a community setting is extremely safe. An overall ADR rate of $2.5 \%$ per infusion is well below previous clinical studies. Hanauer et al (15) reported 106 reactions in 2026 infusions (5.2\%). Of all acute ADRs reported to arise from the 20,976 infusions, none were so severe as to require an intervention of greater than what was provided by existing medical directives. No monitoring other than vital signs and oxygen saturation was required, and no specific physician intervention was required. All cases in which the initiation of an emergency medical service response was mandated by protocol were improved or resolved before arrival of the paramedics.

The present study examined the largest cohort of infusions reported to date and demonstrated that infliximab can be safely infused in the community setting, provided standardized protocols are used. Severe adverse events were extremely rare, none of which required active physician intervention; nurses were able to treat all reactions by following established medical directives. It may be possible to provide such infusions without immediate physician response or on-site presence, and rely on emergency medical service response for truly exceptional events.

The retrospective nature of the study limits the quality and depth of the information available because the data were originally collected for patient care and administrative purposes rather than for research. Therefore, updated information regarding comorbidities and concomitant medications was not available, nor was valuable information regarding the follow-up of severe reactions unless the patient subsequently returned to the clinic for another infusion. A greater level of communication between clinics and referring physicians would address this issue and improve future infusions because lessons learned could also be shared between referring physicians via the clinics. There was a risk of incorporation bias: patients who had experienced severe ADRs before this data collection period would probably have been taken off infliximab. This should have been offset by the ongoing recruitment of new patients. There is the possibility that patients who were more ill would have had their initial infusions during a hospital admission, rather than in a community clinic; however, significantly more than $95 \%$ of our patients have their three loading doses administered in our clinics. Our patients, therefore, appear to highly represent the complete spectrum of disease seen in adolescents and adults.

ACKNOWLEDGEMENTS: The authors acknowledge Debra King, Stephen Hamilton, Julie Yake and the infusion administration staff for their assistance.

CONFLICTS OF INTEREST: The authors report no financial or other conflicts of interest related to this article. No funding was received for the completion and publication of this study.

\section{REFERENCES}

1. Feldmann M, Brennan FM, Maini RN. Role of cytokines in rheumatoid arthritis. Annu Rev Immunol 1996;14:397-440.

2. Goekoop-Ruiterman YPM, De Vries-Bouwstra JK, Allaart CF, et al. Clinical and radiographic outcomes of four different treatment strategies in patients with early rheumatoid arthritis: A randomized, controlled trial. Arthritis Rheum 2005;52:3381-90.

3. Maini RN, Breedveld FC, Kalden JR, et al. Therapeutic efficacy of multiple intravenous infusions of anti-tumor necrosis factor-alpha: Monoclonal antibody combined with low-dose weekly methotrexate in rheumatoid arthritis. Arthritis Rheum 1998;41:1552-63.

4. Reimund JM, Wittersheim C, Dumont S, et al. Increased production of tumour necrosis factor-alpha interleukin-1 beta, and interleukin-6 by morphologically normal intestinal biopsies from patients with Crohn's disease. Gut 1996;39:684-9.

5. Rutgeerts P, Vermeire S, Van Assche G. Biological therapies for inflammatory bowel diseases. Gastroenterology 2009;136:1182-97.

6. Stack WA, Mann SD, Roy AJ, et al. Randomised controlled trial of CDP571 antibody to tumour necrosis factor-alpha in Crohn's disease. Lancet 1997;349:521-4.

7. Cheifetz A, Mayer L. Monoclonal antibodies, immunogenicity, and associated infusion reactions. Mt Sinai J Med 2005; $72: 250-6$.

8. Leman JA, Burden AD. Treatment of severe psoriasis with infliximab. Ther Clin Risk Manag 2008;4:1165-75.

9. Scallon BJ, Moore MA, Trinh H, Knight DM, Ghrayeb J. Chimeric anti-TNF-alpha monoclonal antibody cA2 binds recombinant transmembrane TNF-alpha and activates immune effector functions. Cytokines 1995;7:251-9.

10. Gardam MA, Keystone EC, Menzies R, et al. Anti-tumour necrosis factor agents and tuberculosis risk: Mechanisms of action and clinical management. Lancet Infect Dis 2003;3:148-55.

11. Lees CW, Ali AI, Thompson AI, et al. The safety profile of anti-tumour necrosis factor therapy in inflammatory bowel disease in clinical practice: Analysis of 620 patient-years follow-up. Aliment Pharmacol Ther 2009;29:286-97.

12. Listing J, Strangfeld A, Kekow J, et al. Does tumor necrosis factor alpha inhibition promote or prevent heart failure in patients with rheumatoid arthritis? Arthritis Rheum 2008;58:667-77.

13. Menter A, Reich K, Gottlieb AB, et al. Adverse drug events in infliximab-treated patients compared with the general and psoriasis populations. J Drugs Dermatol 2008;7:1137-46.

14. Patel RV, Clark LN, Lebwohl M, Weinberg JM. Treatments for psoriasis and the risk of malignancy. J Am Acad Dermatol 2009;60:1001-17.

15. Hanauer SB, Feagan BG, Lichtenstein GR, Mayer LF. Maintenance infliximab for Crohn's disease: The ACCENT I randomised trial. Lancet 2002;359:1541.

16. Colombel J, Loftus EV, Tremaine WJ, et al. The safety profile of infliximab in patients with Crohn's disease: The Mayo Clinic experience in 500 patients. Gastroenterology 2004;126:19-31.

17. Takeuchi T, Tatsuki Y, Nogami Y, et al. Postmarketing surveillance of the safety profile of infliximab in 5000 Japanese patients with rheumatoid arthritis. Ann Rheum Dis 2008;67:189-94. 


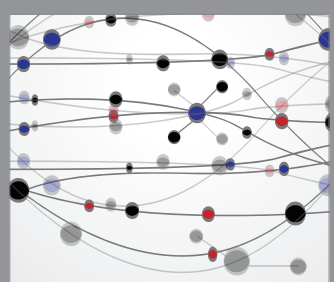

The Scientific World Journal
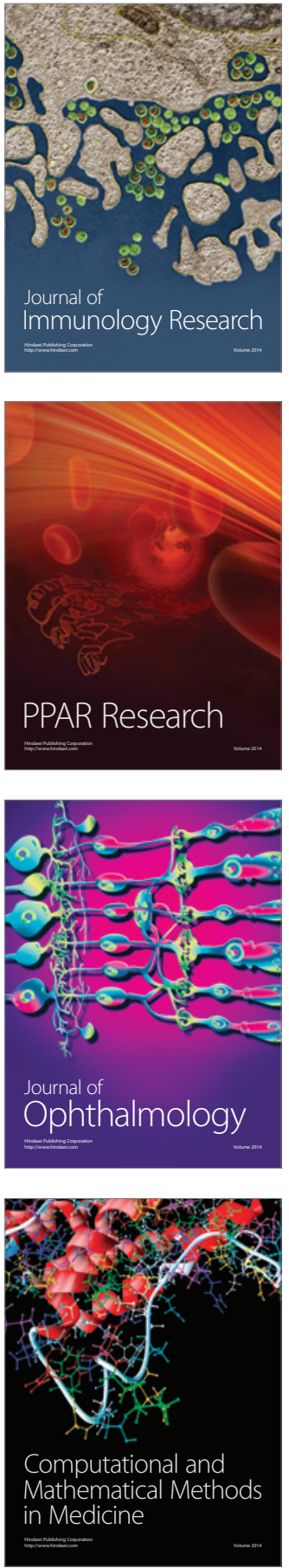

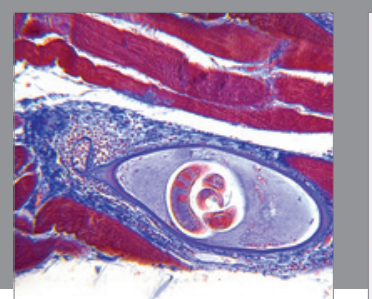

Gastroenterology Research and Practice

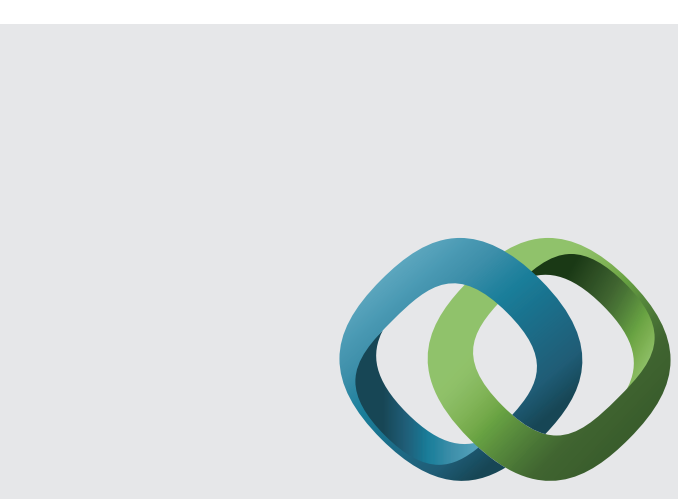

\section{Hindawi}

Submit your manuscripts at

http://www.hindawi.com
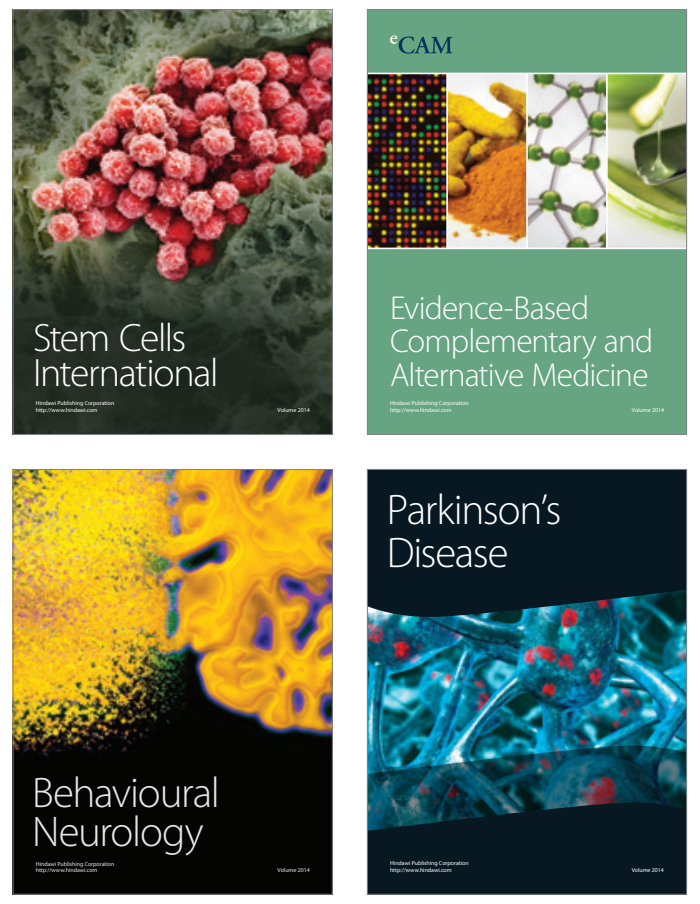
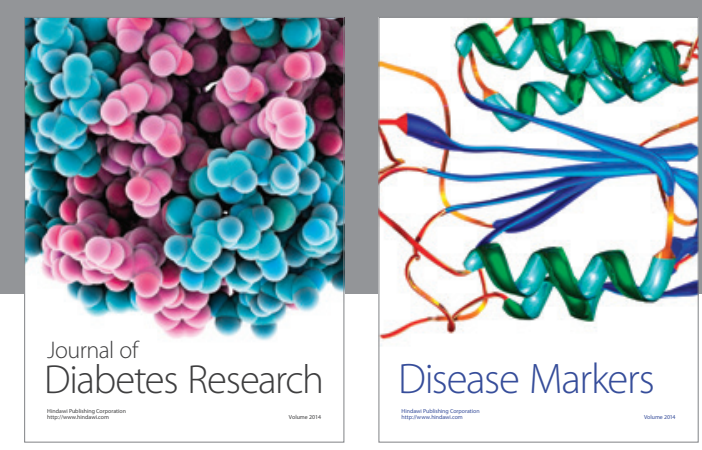

Disease Markers
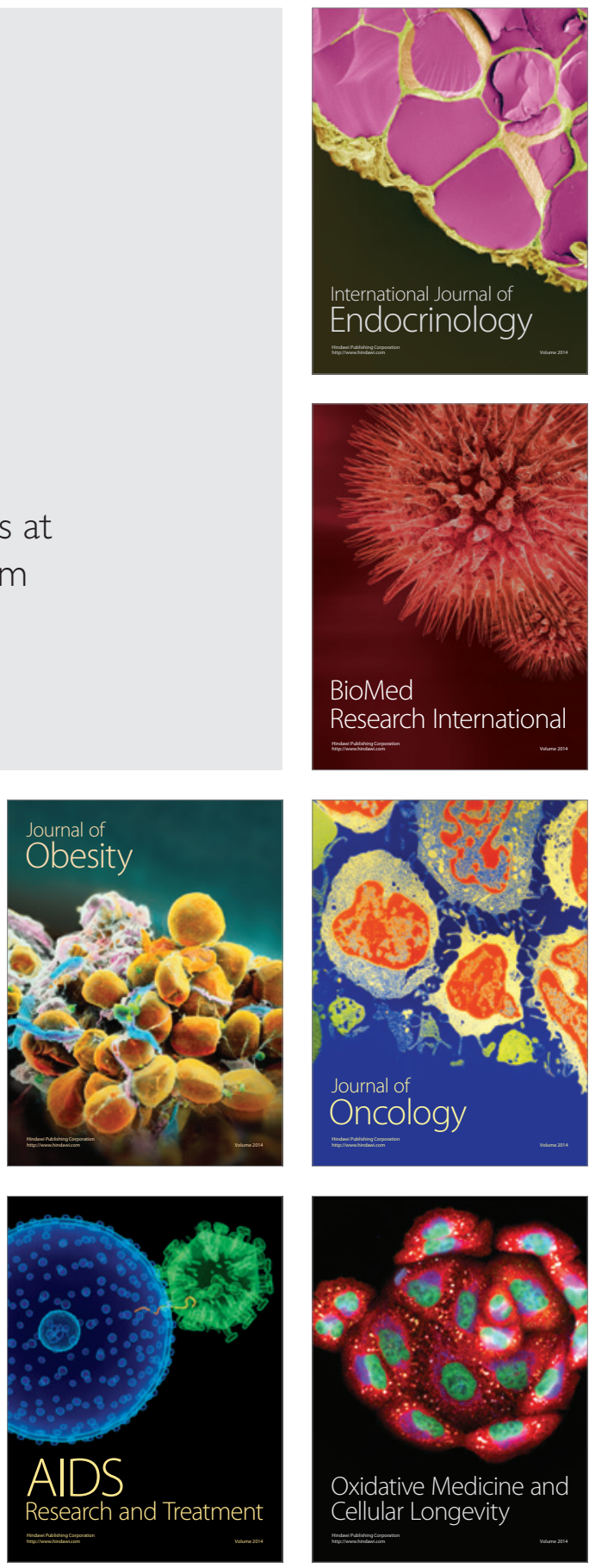